\title{
СОВРЕМЕНАТА ГРЧКА ИСТОРИОГРАФИЈА ЗА ОСМАНЛИСКА МАКЕДОНИЈА Некои размислувања по 1995 година
}

\section{Кратика сооржина}

Познавањейо на исииориоїрафиииее иито се занимаваай со макеоонскайа иситорија е мноіу важно не само за историчарииее, иукку и за йоширокайа јавносй. Мноту честио ирреку иситориоірафијайа може яа се иочувсиивува и йулсой на еяна оржава или ойшитесивво кон оруїа, во овој случај кон Макеоонија. Сосеянийе иситориоірафии не се исклучок оя изнесенайа консйайачија. За жал, со исклучок на йолибералнииее мислители, иситориоірафијайа мноіу чесйо е йоо влијание, намерно или ненамерно, на йолииичкийе состојби во еяна оржава, яури и во оние шито се смейаай за најяемокрайски. Таков е и случајой со современайа ірчка иситориоірафија која се занимава со макеяонскойо минайо, кое іо ілеяа, ілавно, како яело оя минайойо на Гриија.

\section{Клучни зборови: ГРЦИЈА, МАКЕДОНИЈА, ИСТОРИОГРАФИЈА}

Проблемот што го има нашата држава со соседна Грција околу уставното име на Република Македонија не е несериозен и безначаен кој ги тангира само политичките елити што го создадоа, профитираа и сѐ уште живеат од него, најчесто во Грција, иако и нашата земја не е имуна на тоа. Нашето непознавање на грчката историографија, тука пред сѐ мислам на непознавање од страна на историчарите, придонесе да сѐ анализираат низ историска призма жестоките грчки реакции на создавањето на независната македонска држава. Во Солун беше направена и веб-страница на која грчките историчари, особено оние од северна Грција, ги ставаа своите статии што се поврзани со македонското прашање и македонската историја (www.macedonian-heritage.gr). Создавањето на веб-страницата е направено поради појавата, како што е наведено, на една независна македонска држава под привременото меѓународно име Поранешна Југословенска Република Македонија. Исто така, за жал, во македонската јавност се создаде еден впечаток дека грчката држава го забранувала и не го употребувала македонското име сѐ до крајот на 80-тите години на минатиот век. Тоа воопшто не беше точно. Грција не признаваше постоење на посебен македонски етнички идентитет, бидејќи, според нејзините гледања, таков не постоел. Другата страна како едвај да дочека таков аргумент со цел полесно да го отфрли, да не кажам да го исмее, и да ја засили својата активност со докажување како уште од самите почетоци на грчката држава во 30-тите години на XIX век Македонија била сметана и барана како грчка земја. Така, во Солун беше издадена една книга во која се наведени примери како се користел зборот Македонија во Грција, но и од страна на Грците пред 
создавањето на грчката држава. ${ }^{1}$ Самиот наслов на книгата „Македонија - грчки термин во модерна употреба“" го дава одговорот за целта на оваа книга. Сепак, едно мора да признаеме. Грчката историографија, односно, да бидам попрецизен, грчките историчари многу повеќе се запознати со нашата историографија. Во 2010 година грчкиот историчар Василис Гунарис издаде една книга која се однесува на историографијата за македонското прашање. ${ }^{2}$ Дел од оваа монографија е посветена и на македонската историографија. Знам дека многумина ќе кажат нивната држава е постара, државата е поголема итн. Тука не би можел да се спротивставам, но, сепак, мора да признеме дека пропуштивме голем период кој тешко ќе може да го надополниме.

Доколку напишам дека Македонија зазема видно место во современата грчка историографија нема да откријам топла вода. Истото тоа може да се каже и за бугарската историографија. Сепак, кога е во прашање грчката историографија, вообичаено се пишува дека оваа област е историски грчки регион, кој во текот на средниот век бил населен и со многубројно словенско население. Интересот за регионот Македонија кај грчките историчари датира уште од средината на XIX век. Во ова излагање нас тоа нѐ интересира. Вниманието ќе го насочиме кон тоа како грчките историчари гледаат на Македонија која била под османлиска власт. Тука ќе се ограничиме на периодот од почетокот на XIX век па cè до Балканските војни, чијашто стогодишнина следната година беше во центар на научната и општествената јавност, медиумите и, секако, политичарите. Треба да напоменеме дека нашиот интерес е привлечен од ставовите на грчките историчари за османлиска Македонија, по потпишувањето на Привремената спогодба помеѓу Република Македонија и Грција во септември 1995 година. Имено, во периодот кој претходеше на потпишувањето на Спогодбата од Њујорк во Грција, најверојатно, повеќе влијание имаа квазиисторичарите или аматерите отколку професионалните научници, иако, за волја на вистината, и тие не беа имуни на бранот на национализмот и разбрануваните емоции. Гунарис и Михаилидис, во една своја статија, за ова прашање истакнуваат дека нестручни, од лични мотиви и повеќе со емоции отколку со професионално чувство започнале да сечат и лепат тоа што сметале дека е корисно завршувајќи со различни приоди со „сомнителна академска вредност“. ${ }^{3}$ Од друга страна, професионалните историчари, како што напоменуваат двајцата горенаведени грчки научници, конечно, се зафатиле со некои жешки прашања. ${ }^{4}$ Тука ќе се задржиме само на ставовите на историчарите за османлиска Македонија. Нема да користам некои дела на антрополозите или на социолозите во кои се објаснуваат одредени процеси во регионот. Исто така, нема да користам и некои зборници со грчки дипломатски документи и сеќавања на учесниците во некои од настаните во Македонија, кои во последните десетина години беа објавени во соседна Грција. Тие говорат сами за себе. Во овој прилог ке се задржам на две теми за кои мислам дека се

\footnotetext{
${ }^{1}$ MAKESONIA. A Greek term in modern usage, Museum of the Macedonian struggle, Thessaloniki, 2005

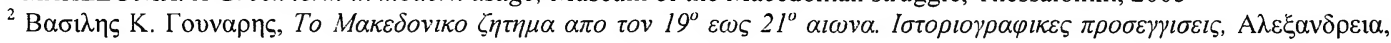
A $\theta$ ᄁva, 2010

' Василис Гунарис и Јаковос Михаилидис, Перото и мечот: преглед на историографијата за македонското прашање, во: Викйор Руяомейов, Макеоонскойо йращање, Евро-Балкан пресс, Скопје, 2003, с.172

${ }^{4}$ исто
} 
интересни. Првата се однесува на тоа како грчките историчари гледаат на границите на регионот Македонија, а втората - на населението.

Гранищитее. Вилкинсон, во своето познато дело во кое пишува за етнографската картографија на Македонија, уште на самиот почеток забележал дека едвај два авторитета бе се согласиле за точниот опис на Македонија, ${ }^{5}$ поточно на нејзините граници. Како и да е, постои една општа согласност до каде се протега географскиот регион Македонија „Границата на географска Македонија ја сочинуваат планините Шар Планина, Скопска Црна Гора, Козјак, Осогово и Рила на север, западните падини на Родопите и долното течение на реката Маста (Нестос) на исток, Егејско Море и реката Бистрица (Алијакмон) на југ и масивот Грамос, Преспанско Езеро, Охридско Езеро и планинските венци Кораб и Јабланица на запад, кон Албанија“. 6 Меѓутоа, кога ги читаме грчките историчари, иако ги признаваат овие граници на регионот Македонија, кога е во прашање османлиска Македонија од почетокот на XIX век до Балканските војни, забележуваме нешто интересно. Имено, постоење на две Македонии - едната од античкиот период и другата од крајот на XVIII и почетокот на XIX век. Познатиот грчки историчар Евангелос Кофос, во една своја студија за грчкиот поглед на нерешеното прашање за името на нашата држава, забележал дека помеѓу Грците постоел еден традиционален поглед кој сметал дека географскиот регион Македонија се протегал на север до Шар Планина, но, исто така, постоел и еден подруг, според него, нов поглед, според кој географскиот и историскиот регион Македонија речиси целосно се совпаѓа со денешна грчка Македонија. ${ }^{7}$ На тој начин Кофос ни покажува и укажува на еден проблем околу границите на регионот Македонија кој се појавува во грчката историографија, а истиот тој е поврзан и со османлиска Македонија и со сегашноста. Во следниот дел од мојот прилог ке посочам на таквите примери. Димитрис Керидис, во својот историски речник за Грција, пишувајќи за регионот Македонија, напоменува дека Македонија е регион во Грција, но, исто така, споменува дека на територијата на Македонија постои и нашата држава. ${ }^{8}$ Георгиос Минцис, во една своја книга која се однесува на македонското прашање, напишал дека историски е установено дека „античката грчка или класична Македонија никогаш не се протегала посеверно од линијата Охридско Езеро - Битола - Струмица - Неврокоп“. ${ }^{9}$ Со други зборови, останатиот дел не припаѓа на Македонија. Јоанис Колиопулос пишува за две Македонии, едната, како што забележал, античка грчка земја, а другата претставува современиот географски регион. ${ }^{10}$ Тука морам да напоменам дека Колиопулос пишува за создавање на современиот регион Македонија. Гунарис, пишувајќи за Битола, забележал дека регионот Македонија, кој се состоел од трите вилаети - Битолски, Солунски и Косовски е многу поголем „отколку античкото Македонско Кралство, денешна грчка Македонија или Поранешната

\footnotetext{
${ }^{5}$ Х. Р. Вилкинсон, Карииитее и йолиииикайа. Претлео на е йноірафскайа карииоірафија на Макеоонија, Македонска книга, Скопје, 1992, с. 35

${ }^{6}$ Ендрју Росос, Макеоонија и Макеяониийе, исйорија, Фондација Институт отворено општество, Македонија, Скопје, 2010, с. 1

${ }^{7}$ Evangelos Kofos, The unresolved "Difference over the name": A Greek perspective in: E. Kofos, V. Vlasidis (ed.), Athens-Skopje. An uneasy symbiosis, ELIAMEP, Athens, 2005, p. 131-132

${ }^{8}$ Dimitris Keridis, Historical Dictionary of Modern Greece, Scarecrowpress, 2009, p. 99-103

${ }^{9}$ Gerogios Mintsis, History of Macedonian question, Society for Macedonian Studies, Thessaloniki, 1998, p. 14

${ }^{10}$ Ioannis Koliopoulos, The shaping of the new Macedonia, in: History of Macedonia, Thessaloniki, 2007, p. 169
} 
Југословенска Република Македонија“. ${ }^{11}$ Во една своја книга посветена на историографијата и македонското прашање, Гунарис дава одлично објаснување за прашањето до каде Грците при крајот на XIX и почетокот на XX век ја гледале Македонија. За Грците од тој период Македонија ги опфаќала „денешната територија на грчка Македонија, најголемиот дел од ПЈРМ и т.н. бугарската - Пиринска. Во практика, меѓутоа, грчката политика и мисла за Македонија ја остави на маргината т.н. тогаш 'Горна Македонија', областа северно од Охрид, Битола, Струмица и Мелник“. ${ }^{2}$ Неговиот колега од Солунскиот универзитет, Спиридон Сфетас, е многу подиректен. Според него, Грција на крајот од XIX и почетокот на XX век има аспирации кон „историска Македонија (денешниот грчки дел и линијата Охрид - Битола - Струмица - Мелник)...“. ${ }^{13}$ За разлика од него, Ливаниос, пишувајќ́ околу прашањето што се подразбирало под Македонија, забележал дека некои грчки историчари го исклучувале Косовскиот вилает од Македонија. ${ }^{14}$ Сволопулос споменува три зони во Македонија од кои во јужната доминирало грчкото население, бугарското во северната, а во средната зона населението било измешано. ${ }^{15}$ Сите овие размислувања околу две Македонии или постоење на историска Македонија или на три зони во османлиска Македонија се во корелација со прифатениот став за континуитет на грчката нација од антиката до денес, иако во последно време некои историчари, како што е Андонис Лијакос, критички се осврнуваат на овој поглед, а Македонија како дел од античката грчка култура и традиција е составен дел од тој континуитет. Кога е во прашање поделбата на регионот, тоа е веќе одомаќена поделба на Македонија на два дела или, пак, на три зони уште од осумдесеттите години на XIX век. Идеен творец на оваа поделба на регионот Македонија бил основоположникот на модерната грчка историографија, Константинос Папаригопулос. Во овој прилог нема да се задржам на прашањето како Папаригопулос ја направил таа поделба, туку само ќе споменам дека таа настанала како резултат на грчките политички потреби во последните две децении на XIX век. Кога веќе го споменав Папаригопулос и неговата поделба на Македонија на два дела и три зони, неодминливо мора да го споменеме историчарот Спирос Каравас, кој во една своја статија извонредно го објаснува начинот на кој Папаригопулос дошол до идејата, но и ја извршил поделбата на Македонија на два дела. ${ }^{16}$ Но, да се навратиме на Вилкинсон, а е поврзано со постоењето на историска или географска Македонија. Тој нагласил дека „можеби еднакво се погрешни и обидите да се дефинира Македонија, историски, преку повикување на нејзините политички граници од минатото. В. Колокотронис, грчки историчар, на пример, посветува четиристотини страници и мноштво факсимилни карти за да покаже, неубедливо, дека северната граница на класична Македонија е речиси слична со онаа на современа Грција. А тоа е веќе

\footnotetext{
"Basil C. Gounaris, From peasants into urbanities, from village into nation: Ottoman Monastir in the early twentieth century , European History Quarterly, v. 31(1), SAGE publications, London,2001, p. 60, f. 1

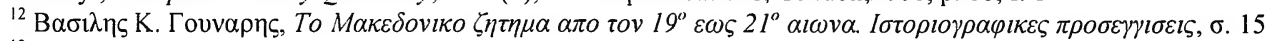

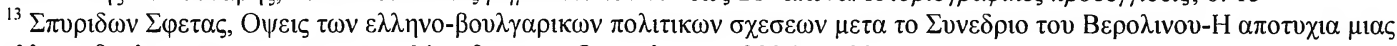

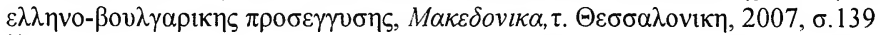

${ }^{14}$ Dimitris Livanios, The Macedonian question. Britain and the southern Balkan 1939-1949, Oxford University Press, 2008, p. 3

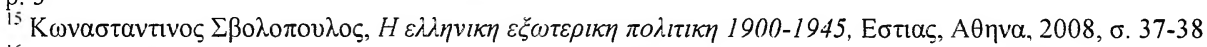

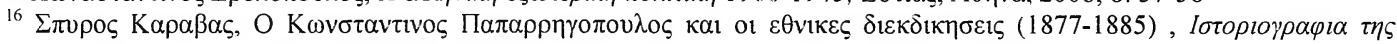

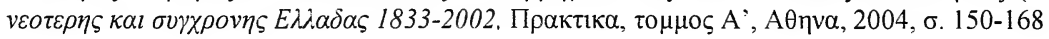


навредливо. Но, историчарите кои се помалку преокупирани со пропагандната вредност на своите истражувања ги откриваат со традиционалниот, минлив карактер на македонските политички граници.. Донесени до границите на Солун, во извесни периоди на својата класична историја, во некои други периоди Македонија достигнува до Јадранско Море, Хаемус и Дунав. Според ова, не се постигнати никакви корисни цели со тоа што се инсистира на хипотетичната стабилност на историските граници на Македонија... не е неразумно да се заклучи дека историјата повеќе не го става својот печат на границите на Македонија како што го прави тоа физичката географија“. ${ }^{17}$ Кон овој став на Вилкинсон може да додадеме и едно интересно мислење на Спирос Каравас, кој пишувајќи за тоа како Папаригопулос стигнал до идејата за поделба на Македонија на зони заклучил дека на крајот и самиот одбил, на едно барање на грчкиот министер за надворешни работи, да даде историско оправдување на линијата која ја делела Македонија на два дела. ${ }^{18}$ На крајот од овој дел, би сакал да го споменам мислењето во однос на границите на регионот Македонија, кое ни дава одговор зошто, и покрај јасните граници на споменатиот регион, и денес сретнуваме мислења што ни изгледаат анахрони и исполитизирани. Имено, еден историчар од постарата генерација, Константинос Вавускос, во една своја статија пред неколку години посветена на македонското прашање, ни дава еден одговор на прашањето зошто и денес се пишува за границите на регионот Македонија, иако знаеме дека тие се менувале низ историјата. Според него, територијата на денешната македонска ${ }^{19}$ држава нема ни најмала врска со историска Македонија, бидејќи во неа се само Битола, Мариово и Струмица. $^{20}$ Значи, на крајот, стигнуваме до причината зошто се инсистира на терминот историска Македонија - античка Македонија нема врска со границите на современиот регион Македонија.

Темата околу границите на османлиска Македонија и нејзината поделба на три зони може да ја сретнеме и во некои училишни дополнителни материјали за историјата. Во Атина, во 2002 година, Педагошкиот институт издаде една книга која беше наменета за учениците во грчките лицеи. Оваа книга со наслов „Историски теми“ била објавена, како што нагласуваат од Педагошкиот институт, заради чисто и одговорно информирање за некои теми кои во последните години биле од голем интерес за јавното мислење во Грција. ${ }^{21}$ Една од темите на оваа книга е македонското прашање. За авторот на овој дел од учебното помагало, според јазичниот критериум, територијата на османлиска Македонија можела да се подели на три зони. Првата зона во која доминирале оние што говореле грчки, заедно со извесен број Евреи. Оваа зона ја опфаќала половината од територијата на грчка Македонија. Втората зона била јазично мешана во која живееле оние што говореле словенски, грчки, албански и влашки. Таа зона ги опфаќала останатиот дел од денешна грчка Македонија, како и една третина од територијата на Република Македонија. Третата, северна, зона во која населението говорело словенски го опфаќала останатиот дел од

\footnotetext{
${ }^{17}$ Х.Р., Вилкинсон, Карийийе и йолийикайа, с. 37

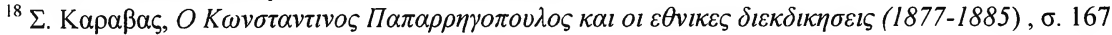

${ }^{19}$ Вавускос не го користи името Република Македонија за означување на државата.

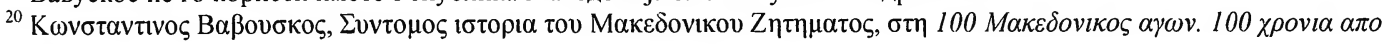

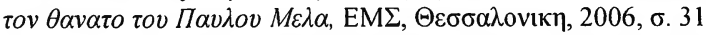

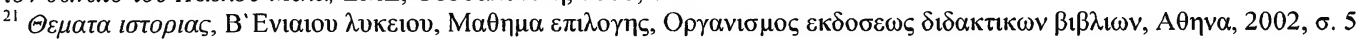


територијата на денешна Република Македонија, како и Благоевградскиот округ или Пиринска Македонија. ${ }^{22}$ Според Евангелос Кофос, кој е и автор на делот од учебното помагало кое се однесува на македонското прашање, главната борба помеѓу Бугарите и Грците за Македонија се водела во јужната и во средната зона. Тука, како што е напишано, Грците имале предност поради поволната етнолошка состојба и поради територијалните барања што се совпаѓале со територијата на античкото македонско кралство, кое Грците го сметаат за свое. ${ }^{23}$ Така и грчките ученици се запознаваат со една подруга дефиниција на границите на регионот Македонија.

Музејот на македонската борба во Солун има релативно развиена издавачка дејност која се однесува на македонското минато. Во тие рамки, во Музејот веќе десетина години се организираат изложби на фотографии посветени на разни теми од македонската минато под османлиска власт, такво како што го гледаат во Грција. По завршувањето на изложбите, фотографиите заедно со соодветен текст се печатат во една книга во форма на календар. Интересно, и во овие книги во форма на календар кога се во прашање границите на Македонија може да забележиме дека северните делови од регионот не се застапени во тие изложби и книги. Така, во изданието посветено на македонското општество од почетокот на $\mathrm{XX}$ век, може да забележиме дека „три четвртини од населението во Битолскиот и четири петтини од Солунскиот вилает биле земјоделци“. ${ }^{24}$ Воопшто нема ниту еден збор за деловите од Косовскиот вилает кои биле дел од османлиска Македонија.

Во 2004 година, во Грција со многу прослави, говори, конференции и издавање на разни материјали беше одбележана 100-годишнината од почетокот на т.н. македонска борба. Во одбележувањето на овој значаен јубилеј за Грците, активно учествуваа и научниците, посебно историчарите. Во рамките на оваа прослава во Солун, беше одржана една изложба на карти што се однесувале на македонското прашање од 1870 до 1930 година. Целта на оваа изложба беше да се прикаже картографското наследство за Македонија од крајот на XIX век до вклучувањето на Македонија во составот на грчката држава. Како резултат на оваа изложба излезе една книга со иста тема и наслов "Мapping Macedonia 1870-1930". Книгата обилува со разни карти кои претежно се однесуваат на етнографските и политичките состојби во Македонија во наведениот период. Сепак, двајцата автори на текстовите што ги придружуваат картите, историчарот Јаковос Михаилидис и картографот Евангелос Ливиератос, не навлегуваат околу прашањето за поделба на Македонија на два или три дела. Сепак, прашањето на границите на османлискиот регион Македонија постепено се отвори и на темата картите и историјата. Заострувањето на односите помеѓу двете соседни држави Република Македонија и Грција пред Самитот на НАТО во Букурешт во 2008 година, кое кулминираше со грчко вето на македонското придружување кон Северноатлантскиот сојуз, доведе и до ангажирање на научниците од двете земји за покажување на сопствената вистина. Во Грција, во 2008 година, беше издадена една книга која имаше цел да ги прикаже грчките погледи за историјата на Македонија, македонското прашање и спорот за уставното име на Република

\footnotetext{
22 исто, с. 46

23 исто

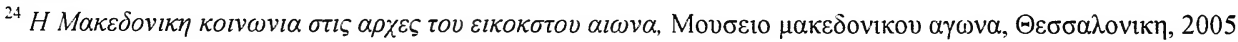


Македонија. Во оваа книга повторно го сретнуваме терминот историска Македонија, кој е поврзан со античката македонска држава. ${ }^{25}$ Авторот на оваа статија, професорот на Солунскиот универзитет Евангелос Ливиератос, отиде чекор понатаму во толкувањето на картографијата и политиката. Тој, веќе како министер во грчката влада, заедно со Хрисула Палијадели, професорка по археологија на Солунскиот универзитет и пратеничка во Европскиот парламент, неодамна издаде една книга која се однесува на европската картографија и Македонија. Во неа може да прочитаме дека во текот на XIX век доаѓa менување на границите на регионот Македонија, кој бил дел од Османлиската Империја, на европските карти. Значи, повторно се прави една разлика во границите на регионот Македонија во антиката и во XIX век. За разлика од изданието од 2004 година, новата книга има јасна цел. Имено, според авторите на оваа книга, главната цел на студијата била да се покаже дека географијата и картите може да помогнат во подоброто и побалансирано разбирање на денешното македонско прашање, посебно околу дебатата, според нивното размислување, за погрешното користење на историскиот термин. ${ }^{26}$ Овој дел од заклучокот на книгата најдобро говори зошто таа била потребна.

Население. Во грчката историографија, кога е во прашање составот на населението, сѐ уште доминира едно клише во кое се говори за Словени, словеногласни Грци, Бугари, понекогаш Срби, Славомакедонци и многу ретко за Македонци. Во оваа своја мала статија посветена на некои погледи на грчката историографија за османлиска Македонија, ќе се осврнам на некои интересни погледи на повлијателни грчки историчари околу составот на населението и неговото именување. Иако на прв поглед доминира клишето дека еден дел од составот на населението недостасува во нашите очи, едно повнимателно читање навистина може да изненади. За Миранда Паксимадопулу-Ставрину, населението во Македонија било мешавина помеѓу Грци, Словени, Турци, Власи, Евреи и Албанци. Кога е во прашање македонскиот идентитет, таа заклучува дека тој бил локален, месен, но не и етнички. ${ }^{27}$ Еден од водечките и влијателни грчки историчари од постарата генерација - Јоанис Колиопулос во неколку свои книги се осврнува и на составот на населението во османлиска Македонија, поточно на оние делови од областа кои подоцна ќе ѝ припаднат на грчката држава. Како и за другите грчки историчари, Македонија е населена со различни народи. Кога се во прашање Македонците, како посебен народ, Колиопулос пишува за Бугарите кои во XX век се нарекуваат Славомакедонци. ${ }^{28}$ Според него, расположливите извори не дозволуваат барање во далечното минато на еден почеток на посебен, според него, „македонски“ национален идентитет што бил создаден во XX век. ${ }^{29}$ За волја на вистината, Колиопулос дава неколку примери како некои грчки интелектуалци го нарекувале македонското словенско население во османлиска Македонија. Тука би ги споменал примерите на Павлос Мелас, кој за Македонците го користи името кое нам ни е познато и тоа без префикси,

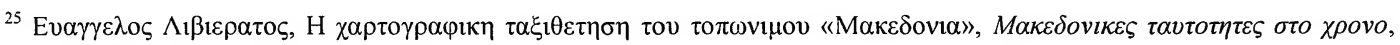

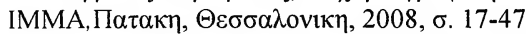

${ }^{26}$ Evangelos Livieratos, Chrysoula Paliadeli, European cartography \& politics; the case of Macedonia, Ziti publications, Thessaloniki, 2013, p. 141

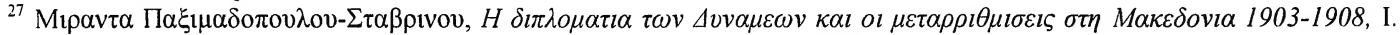
$\Sigma \eta \delta \varepsilon \rho \eta \varsigma, ~ A \theta \eta v \alpha, 2009, \sigma .57$

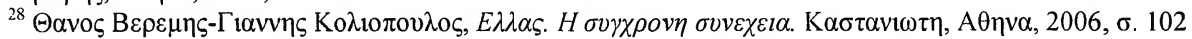

${ }^{29}$ исто
} 
суфикси и наводници, но и примерот на Неоклис Казазис, кој го делел словенското население во османлиска Македонија на Срби, Бугари и словеногласни Македонци. ${ }^{30}$ Тука мора да забележам дека оваа информација ја нема во англиското издание на истата книга, која претходеше на грчкото. Инаку, Колиопулос првпат ги дава овие податоци во една своја книга посветена на историјата на Грција од 1800 година наваму, која била наменета за студентите на Универзитетот Аристотел во Солун. ${ }^{31}$ Професорот на Универзитетот Аристотел во Солун Василис Гунарис напиша една книга која е посветена на градот Битола. Во едно реномирано европско историско списание, Гунарис издаде една статија која е поврзана со неговата книга посветена на споменатиот македонски град. За нашата тема е интересна една негова опсервација. Имено, кога пишува за социјалниот живот во егзархиската заедница во градот, иако нагласува дека ниту еден бугарски, грчки или друг европски извор не сведочел за видлива разлика внатре во егзархиската заедница во почетокот на XX век, сепак, забележал дека социјалното раслојување во нејзините рамки придонело новодојдените повеќе да бидат приврзани кон македонската независност отколку кон анексијата кон Бугарија. ${ }^{32}$ Оваа мисла на Гунарис не значи дека тој многу отстапува од ставовите на своите колеги, но, сепак, во една своја книга посветена на грчките гледишта за Балканот од времето на просветителството до Првата светска војна, дава интересни податоци за тоа како Грците во минатото гледале на османлиска Македонија. На едно место сретнавме податок кој е интересен за нашата тема. Имено, на страниците на атинскиот печат во 1901 година се појавила информација дека Русите во Македонија откриле нов македонски словенски народ кој не бил ниту бугарски ниту српски. ${ }^{33}$ Во својата книга посветена на прашањето за финансирање на грчките интернати и давање стипендии на ученици од османлиска Македонија, професорката на Јанинскиот универзитет Софија Вури дава многу податоци. Тука треба да споменам дека оваа грчка историчарка е една од поумерените кога се во прашање толкувањата на македонското минато. Оваа нејзина книга е интересна за нашата тема. Кога е во прашање потеклото или јазикот на оние што добивале грчки стипендии или биле во грчките интернати, навидум, и Вури е на линија на тоа што го нарекуваме официјален став на грчката историографија. Сепак, во додатокот кон оваа книга може да сретнеме интересни податоци кои се во спротивност со тврдењата дека не постои македонскиот јазик. Имено, во еден документ, презентиран во оваа книга, во графата за мајчин јазик на учениците во Битолскиот интернат стои - македонски, без префикс, суфикс или наводници. ${ }^{34}$ Потеклото на овој документ е од грчкото Министерство за надворешни работи. За Димитрис Ливаниос, кој е познат по една многу добра анализа за развојот на грчката национална свест, ${ }^{35}$ населението во Македонија било мешавина на разни народи, но вистинското прашање во османлиска Македонија било лојалноста и „националната

\footnotetext{
${ }^{30}$ Исто, с. 103

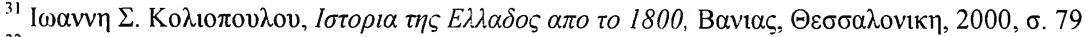

${ }^{32}$ Basil C. Gounaris, From peasants into urbanities, from village into nation: Ottoman Monastir in the early twentieth century, p. 53

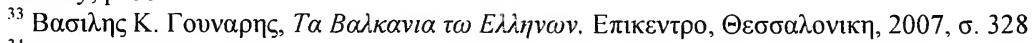

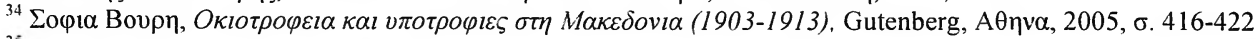

${ }^{35}$ Dimitris Livanios, The quest for Hellenism: Religion, Nationalism and Collective Identities in Greece (1453-1913), The Historical Review/La Revue Historique. Volume III, Athens, 2006, p. 33-70
} 
ориентација“ на словеногласното население, кое било цел на Грците, Бугарите и Србите. ${ }^{36}$ Овој грчки историчар забележува дека повеќето „македонски Словени останале длабоко потопени во предмодерниот верски идентитет на православниот милет...“37 Меѓутоа, Ливаниос нагласува дека во листата недостасувал еден термин - „Македонци“. Тоа, според него, воопшто не било изненадувачко доколку се има предвид дека повеќето Словени ако не се декларирале за Бугари, тогаш се определувале за Грци или христијани. ${ }^{38}$ Сепак, употребата на терминот Македонци не бил непознат за словенското население или за поширокиот свет, но „малкумина би го искористиле во 'национално', како спротивно на регионалното значење за да означат словенска група различна од Србите и Бугарите и влијанието на оние што го правеле тоа не било значајно“. ${ }^{39}$ Ова се однесувало на Мисирков. Ливаниос, кога пишува за Мисирков, не користи наводници за идејата на македонскиот деец за македонски јазик и македонска нација. ${ }^{40}$ Кога веќе го спомнав Мисирков, треба да се се напомене дека во Грција веќе е издадена една поголема студија за овој истакнат македонски деец. За нас од интерес е како авторката на оваа монографија пишува за населението во османлиска Македонија. Ана Ангелопулу, во својата книга за Мисирков, наведува дека населението во трите македонски вилаети кое за свој мајчин јазик ги имало словенските македонски идиоми било нарекувано „Гркомани“, „Србомани“, „Бугари“, „славофони Грци“, „Македонци Бугари“, „Славомакедонци“, „Македонци““" ${ }^{41}$ Кога го споменав последниов термин, Ангелопулу ни дава еден навистина интересен коментар. Имено, објаснувајќи зошто користи наводници кога ги употребува термините „Македонец“ или македонски, Ангелопулу забележува дека ги употребува кога тие се однесуваат на народот, но не за да негира дека постои македонски народ во соседната држава, туку затоа што постојат сомневања дали е завршен процесот на македонската етногенеза. ${ }^{42}$ Спиридон Сфетас, кога пишува за појавата на нациите на Балканот, се осврнува на изградбата на нашиот, како славомакедонски идентитет, со коментар дека Македонците заедно со Бошњаците и Молдавците се вештачки нации создадени од партиските и интелектуалните кругови, а нивната свест се појавила во XX век. ${ }^{43}$ Сепак, Сфетас е многу пофер од Марија Нистазопулу-Пелекиду, која во своето второ и дополнето издание на книгата „Балканските народи“, која се однесува на историјата на регионот од XIV до XIX век, на ниту едно место не споменува постоење на посебно словенско население во Македонија. Дури и на една карта која се однесува на југословенските земји, а границите на тие земји се границите на СФРЈ, може да прочитаме Словенија, Хрватска, Босна и Херцеговина, Црна Гора, Србија, дури и Војводина, но не и Македонија, барем во наводници. Од картата се добива впечаток

\footnotetext{
${ }^{36}$ Dimitris Livanios, The Macedonian question, Britain and the southern Balkan 1939-1949, p. 7

${ }^{37}$ Исто, с. 9

${ }^{38}$ Исто, с. 14

${ }^{39}$ исто

40 исто

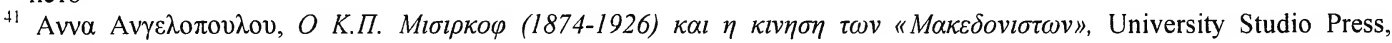

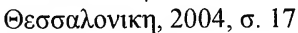

${ }^{42}$ Исто, с. 18

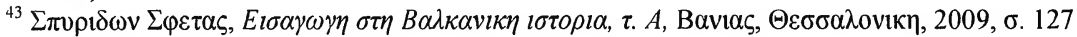


дека територијата на Република Македонија, всушност, е јужен дел на Србија. ${ }^{44}$ Врз база на изнесеното, може да забележиме дека кога е во прашање припадноста на населението во османлиска Македонија во грчката историографија, како и во останатите од регионот на Југоисточна Европа, преовладува мислењето дека регионот претставувал мешавина од разни етнички групи. Кога е во прашањето етничкото македонско население, може да се забележи потенцирање на доцната појава на македонската свест. Тоа и не би било чудно доколку тоа не е со цел да се оправдаат грчките позиции и стекнатото право на името Македонија.

На крајот, може да забележиме дека по потпишувањето на Привремената спогодба помеѓу Република Македонија и Грција во 1995 година, интересот на грчката историографија за македонското минато не е намален и тоа е разбирливо. Улф Брунбауер, во една своја статија за македонската историографија по падот на социјализмот, заклучува дека нашите историчари за своја патриотска должност го сметаат занимавањето со националните прашања. ${ }^{45}$ Оваа негова констатација не е неточна, но каков е односот на грчките историчари. Тука би можеле да го користиме мислењето на еден од подобрите познавачи на историјата на македонското прашање во соседна Грција. Пишувајќи на темата историографијата за македонското прашање, Василис Гунарис забележал дека ова прашање во Грција се наоѓ⿱ помеѓу историографијата и политиката. ${ }^{46}$ Оцената на Брунбауер за македонските историчари може да ја дадеме и на нашите грчки колеги. Имено, како што се наближуваше Самитот на НАТО во Букурешт и најавата за грчко вето поради провокациите и непопустливоста на Скопје околу прашањето за името на Република Македонија, нешто што постојано беше подвлекувано од страна на Атина, стапија на сцена и грчките историчари. Во Солун беше издадена една книга посветена на македонизмот и империјализмот на Скопје од 1944 до 2006 година. ${ }^{47}$ Во неа се дадени сите аргументи што ги ги користи грчката страна против нас за да докаже дека Република Македонија има територијални претензии кон Грција. Речиси истовремено од печат излезе и книга, исто така, посветена на македонизмот, но со тема за „претензиите на ПЈРМ“ по потпишувањето на Привремената спогодба од 1995 година. ${ }^{48}$ Оваа книга беше издадена на англиски јазик. Целта на објавувањето на оваа книга е повеќе од очигледна. Таа е наменета за меѓународната јавност, која треба да биде запозната со иредентизмот на соседната земја. Во овој наплив на книги, грчките историчари издадоа една книга која се однесува на историјата на Македонија од антиката до деведесеттите години на минатиот век. ${ }^{49}$ Оваа книга беше издадена на англиски и на германски јазик. Во неа е даден, многу внимателно, грчкиот поглед на македонската историја. Меѓутоа, тоа не беше крајот. Непосредно по Самитот на

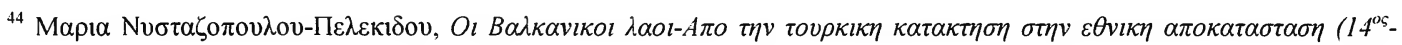

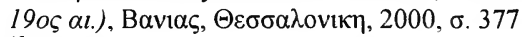

${ }^{45}$ Ulf Brunnbauer, Serving the nation: Historiography in the Republic of Macedonia (FYROM) after Socialism, Historein, V. 4 (2003-2004), p. 175

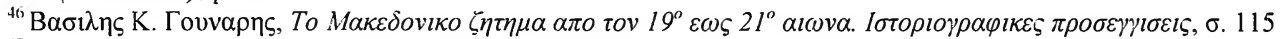

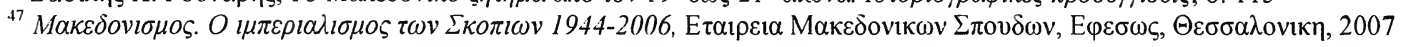

${ }^{48}$ Macedonianism. FYROM'S expansionist designs against Greece after the Interim Accord (1995).Society for Macedonian Studies, Ephesus, Thessaloniki, 2007

${ }^{49}$ The history of Macedonia, (ed. by Ioannis Koliopoulos), Museum of the Macedonian struggle, Thessaloniki, 2007
} 
НАТО во Букурешт, излезе една нова книга посветена на македонските идентитети низ времето. ${ }^{50}$ И оваа книга, како и претходните, го прикажуваше погледот на грчките научници, најголем дел историчари, на проблемите од македонското минато од антиката до современиот период. Книгата наскоро беше преведена на англиски јазик. Овие книги беа издадени од страна на Музејот на македонската борба и Здружението за македонски студии во Солун. Државата има влијание во финансирањето на овие институции. На некој начин, како што кажав и погоре, оцената на Брунбауер за нашата историографија може да ја пренесеме и врз грчката.

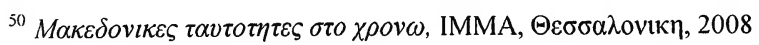




\section{Литерашура}

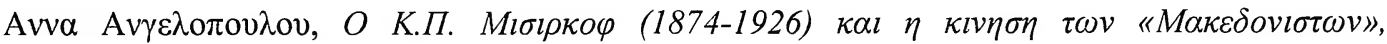

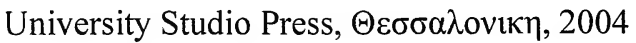

Ulf Brunnbauer, Serving the nation: Historiography in the Republic of Macedonia (FYROM) after Socialism, Historein, V. 4 (2003-2004)

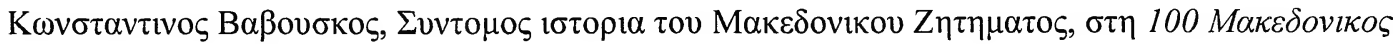

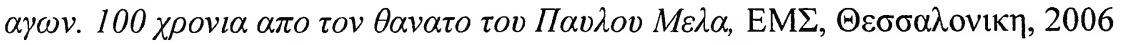

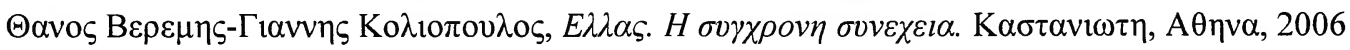
Х.Р.Вилкинсон, Карииийе и йолийикайа. Претлея на ейноірафскайа карииоірафија на Макеоонија, Македонска книга, Скопје, 1992

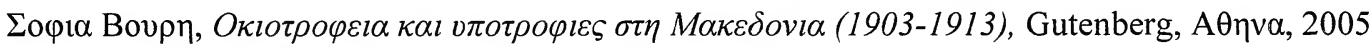

Basil C. Gounaris, From peasants into urbanities, from village into nation: Ottoman Monastir in the early twentieth century, European History Quarterly, v. 31(1), SAGE publications, London, 2001

Василис Гунарис и Јаковос Михаилидис, Перото и мечот: преглед на историографијата за македонското прашање, во: Викӣор Руяомейов, Макеоонскойо йраиање, ЕвроБалкан прес, Скопје, 2003

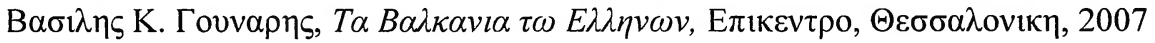

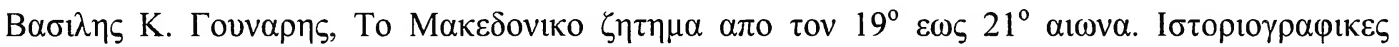
$\pi \rho \circ \sigma \varepsilon \gamma \gamma 1 \sigma \varepsilon 1 \zeta, \mathrm{A} \lambda \varepsilon \xi \alpha v \delta \rho \varepsilon 1 \alpha, \mathrm{A} \theta \eta v \alpha, 2010$

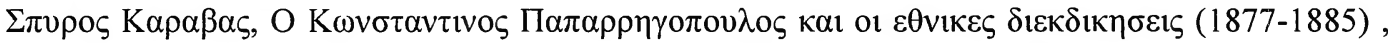

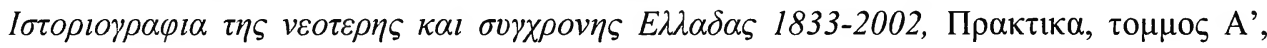
A $\theta$ пva, 2004

Dimitris Keridis, Historical Dictionary of Modern Greece, Scarecrowpress, 2009

Evangelos Kofos, The unresolved "Difference over the name": A Greek perspective in: E. Kofos, V. Vlasidis (ed.), Athens-Skopje. An uneasy symbiosis, ELIAMEP, Athens, 2005

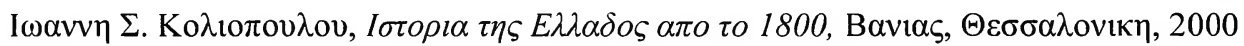

Ioannis Koliopoulos, The shaping of the new Macedonia, in: History of Macedonia, Thessaloniki, 2007

Dimitris Livanios, The quest for Hellenism: Religion, Nationalism and Collective Identities in Greece (1453-1913), The Historical Review/La Revue Historique, Volume III, Athens, 2006

Dimitris Livanios, The Macedonian question, Britain and the southern Balkan 1939-1949, Oxford University Press, 2008

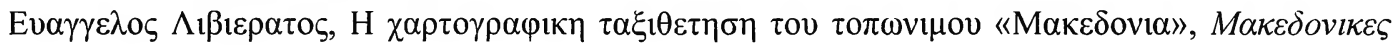

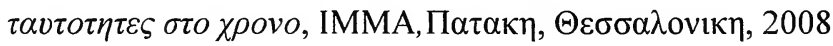

Evangelos Livieratos, Chrysoula Paliadeli, European cartography \& politics; the case of Macedonia, Ziti publications, Thessaloniki, 2013

MAKE $\triangle$ ONIA. A Greek term in modern usage, Museum of the Macedonian struggle, Thessaloniki, 2005 


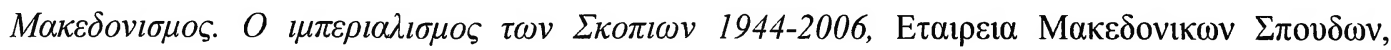

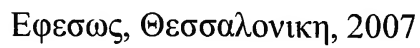

Macedonianism. FYROM'S expansionist designs against Greece after the Interim Accord (1995), Society for Macedonian Studies, Ephesus, Thessaloniki, 2007

Gerogios Mintsis, History of Macedonian question, Society for Macedonian Studies, Thessaloniki, 1998

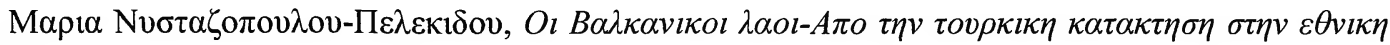
$\alpha \pi \circ \kappa \alpha \tau \alpha \sigma \tau \alpha \sigma \eta\left(14^{\circ \varsigma}-19 o \varsigma \alpha l.\right)$, B $\alpha v 1 \alpha \varsigma, \Theta \varepsilon \sigma \sigma \alpha \lambda o v i \kappa \eta, 2000$

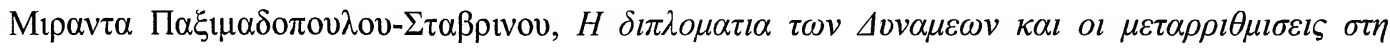

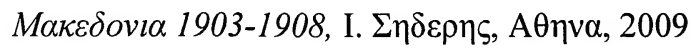

Ендрју Росос, Макеяонија и Макеяониите, иситорија, Фондација Институт Отворено Општество, Македонија, Скопје, 2010

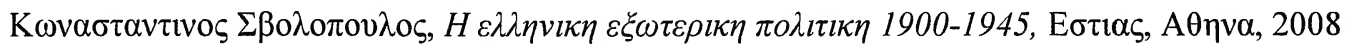

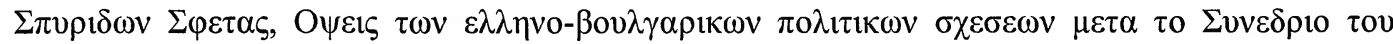

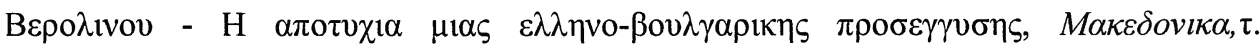

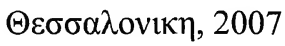

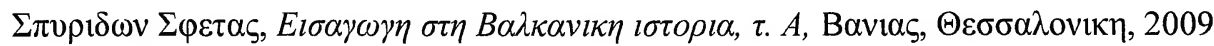

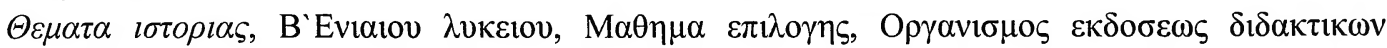
$\beta \iota \beta \lambda \iota \omega v, A \theta \eta v \alpha, 2002$ 
Dalibor JOVANOVSKI

\section{MODERN GREEK HISTORIOGRAPHY ON OTTOMAN MACEDONIA}

\section{Some considerations after 1995}

\section{Summary}

The knowledge of historiography, anthropology, and cartography that deal with the Macedonian past is very important not only for historians, but also for the public. For example, very often through historiography, one can feel the pulse of one state or society towards another, in this case Macedonia. The neighboring scientific views are not exceptions to this fact. Unfortunately, with the exception of the more liberal thinkers, historiography, anthropology, and cartography very often are under the influence, purposely or not, of the political situation in the state, even in those that consider themselves as the most liberal ones. That is the case with the contemporary Greek science that deals with the Macedonian past, which in general is treated, as a part of the Greek past.

Keywords: GREECE, MACEDONIA, HISTORIOGRAPHY 